\title{
Prevalence of Asthma and Other Allergic Diseases in Pregnant Women
}

\author{
Nasrin Fazel1,2, Asghar Kazemzadeh³, Mojtaba Fattahi Abdizadeh³, Erika Jensem-Jarolim \\ Shohreh Shahrouyan ${ }^{5}$, Sina Shahrooyan ${ }^{6}$ \\ Iranian Research Center on Healthy Aging, Department of Medical-Surgical Nursing, \\ School of Nursing and Midwifery, Sabzevar University of Medical Sciences, Sabzevar, Iran \\ ${ }^{2}$ Ph.D. student Center for Public Health, Medical University Vienna, Vienna, Austria \\ ${ }^{3}$ Sabzevar University of Medical Sciences, Sabzevar, Iran \\ ${ }^{4}$ Institute for Pathophysiology and Allergy Research, Medical University Vienna, Vienna, Austria \\ ${ }^{5}$ Msc in English, Hakim University Sabzevar, Iran \\ ${ }^{6}$ Moscow State University of Medicine and Dentistry named after A.I. Evdokimov, Moscow, Russia
}

\section{SUMMARY}

Asthma and allergic disorders can affect the outcome of pregnancy. Asthma and allergies are common comorbidities during pregnancy and exacerbations are the major clinical problem. Results are not consistent between studies.Therefore, the aim of this study was to determine the frequency of asthma and allergic disease during pregnancy.

This prospective cohort study was carried out at the antenatal clinic of Mobini Hospital in Iran. Overall, 1,603 women were enrolled prior to the $24^{\text {th }}$ week of pregnancy. All participants were interviewed for allergy disease, allergic trigger factors and severity of asthma. Also, asthma control was categorized as per GINA guidelines. The diagnosis of asthma was based on symptoms, pulmonologist diagnosis, and spirometry assessment. The results were analyzed using SPSS version 20 and T-tests and Chi-square test.

The prevalence of asthma during pregnancy was $2.1 \%$ among the participants. The most common allergens in asthmatic group were pollen, stress, and climate. There was a significant relationship between age, education and place of living in asthmatic and non-asthmatic group, $p=0.003, p=0.05, p=0.008$, respectively. There was a significant relationship between asthma symptoms among the two groups $(p=$ 0.001). In addition, a significant relationship was found between asthma and other allergic diseases including eczema, allergy, rhinitis, and wheeze in asthmatic women, with a significant relationship between wheeze and coughing and allergy.

Exposure of the pregnant women to high levels of allergens, like pollen, and allergic diseases resulted in an increased risk of pregnancy outcomes. Careful management of these diseases should prevent most of the serious complications.

Key words: allergen, pregnancy, asthma

Corresponding author:

Nasrin Fazel

e-mail: Shohreh1368@yahoo.co.uk 


\section{INTRODUCTION}

Asthma, one of the most important chronic diseases afflicting women of reproductive age, has a prevalence of 2 to $12 \%$. It is assumed that asthma will become even more prevalent in pregnant women (1). Worldwide, studies have been done to determine the prevalence, risk factors, and triggers of the disease (2). However, how pregnancy affects asthma, and vice versa, has not been well-addressed in crosssectional studies, especially in areas with suboptimal asthma control. Some researchers have suggested a rule of thirds, that is: asthma either improves, worsens or is unaffected during pregnancy in one third of women. However, improvements have been mostly determined subjectively, while exacerbations are documented by emergency department visits and hospital admissions. Furthermore, there have been no allowances made for seasonal and regional variations. Another bias of such studies is that asthmatic women have largely been recruited from specialty clinics, not reflecting overall asthma patient distribution (1). Asthma exacerbations during pregnancy (3) are probably due to changes in cell-mediated immunity, predisposing them to more viral infections that may trigger asthma attacks (4). Atopy, however, does not seem to be a cause for exacerbations throughout gravidity. One study has found a higher exacerbation rate in women with non-atopic asthma (5). The ratio of hospital admissions, emergency room visits, and consumption of oral steroids for asthma in pregnancy was significantly higher in blacks than whites, indicating a possible role of socio-demographic characteristics and of health care access (3). Contact with pollen, dust, tobacco smoke, then alcohol, obesity, exercise, stress, gastroesophageal reflux disease are among the reported asthma triggers during pregnancy $(2-6)$.

Risk of almost all adverse pregnancy outcomes increased in a general obstetric population with asthma (4). Uncontrolled asthma has been associated with adverse pregnancy, including untoward effects on the fetus (e.g. prematurity, low birth weight, augmented danger of malformations) due to impaired oxygen transfer (3). On the other hand, some studies found no direct effect of the severity of maternal asthma on birth outcomes and pregnancy complications (5). It has been reported that careful management of asthma and its exacerbations during pregnancy prevents most serious obstetric and neonatal complications, supporting the role of impaired oxygen supply in the pathogenesis of adverse pregnancy outcomes in asthmatics (7-10). While controlled asthma only has a minor effect on mother and fetus, the risk of uncontrolled asthma is significant for both. Asthma triggers during pregnancy are a critical clinical problem and may be associated with adverse pregnancy outcomes $(11,12)$. The need to standardize criteria to determine asthma prevalence during pregnancy and to understand the risk factors and outcomes of pregnancy is the precursor to raising public awareness and disease prevention measures. Therefore, this research was conducted to determine the prevalence of asthma and its triggers in pregnant women in Sabzevar Iran.

\section{PARTICIPANTS AND METHODS}

About 800 pregnant women referred to Mobinini Hospital for delivery were considered for participation in the study. A pilot study was conducted to evaluate the feasibility of implementing the protocol. Based on the low incidence of asthma, sampling was carried out in 1,603 pregnant women. The study was conducted on all women who met inclusion criteria, including pregnant women who were referred to Mobinini Hospital (it is the only hospital in the city where all labors were delivered) and their delivery was performed there; who had previously been diagnosed with asthma, were currently using one of the common asthma drugs, or had recently shortness of breath, cough and wheezing. The study excluded those with a subpar knowledge of Persian, those with severe mental health problems, those with severe respiratory disease like chronic obstructive pulmonary disease or respiratory diseases other than asthma, those having had sinus surgery within the previous 6 months, and those using systemic steroids in the past four weeks or more for illness other than asthma. Spirometry was performed with the Spirolab III $\mathrm{S} / \mathrm{N} 000072$ device in all cohorts. The severity of asthma was assessed based on symptoms and GINA definitions. In the GINA assessment of asthma control, asthma control was assessed from two domains: symptom control and risk factors. Asthma severity is a task force lung function criterion (a pre-bronchodilator FEV1 of $<80 \%$ predicted in the previous year) (13). We conducted a 30-minute interview with 1,603 pregnant women after obtaining their written consent. The study tools were a questionnaire and observation form for spirometric tests. Based on the 
answers to the clinical questionnaire, a woman was considered to have asthma if she answered affirmatively to both questions: "Have you ever had asthma?" and "Was this confirmed by a doctor?". The asthma course during pregnancy was evaluated with the specific question: "What happened to your asthma during your pregnancies? A) got better B) got worse C) stayed the same D) not the same for all pregnancies E) I don't know"(13). Interviews were conducted to obtain demographic information, asthma symptoms or previous asthma diagnosis, allergy disease, allergic trigger factors and known or suspected asthmatics. The pregnant women without asthma were a control group. In this study, we calculated a sample with $95 \%$ confidence, the prevalence of approximately 5\% and an accuracy of $1.5 \%$. This sample size is about 10 percent of pregnant women. Descriptive and comparative statistical (Chi-square, t-test, Fischer's exact test) analyses were performed; also, we set the level of significance at .05\%. All data were entered into a database and exported to SPSS version 20 (IBM, USA).

\section{RESULTS}

Out of 1603 pregnant women screened with the questionnaire, 41 pregnant women were declared positive by this questionnaire, 1 patient was found to be having purely cardiovascular disease, 5 women were found to be having respiratory disor-

Table 1. Frequency of demographic characteristics of asthmatic and non-asthmatic pregnant women referred to Shahidan Mobini Hospital in Sabzevar

\begin{tabular}{|c|c|c|c|}
\hline \multirow[b]{2}{*}{ Variables } & Non-asthmatic & Asthmatic & \multirow[b]{2}{*}{ P-value } \\
\hline & N.\% & N.\% & \\
\hline \multicolumn{3}{|l|}{ Education } & \\
\hline Under high school & $543(80.8)$ & $28(90.3)$ & \multirow[t]{2}{*}{$P=0.18$} \\
\hline Upper high school & $129(19.2)$ & $3(9.7)$ & \\
\hline \multicolumn{3}{|l|}{ Age } & \multirow{3}{*}{$\mathrm{P}=0.001$} \\
\hline Age $<35$ & $610(90.8)$ & $20(64.5)$ & \\
\hline Age > 35 & $62(9.2)$ & $11(35.5)$ & \\
\hline \multicolumn{3}{|l|}{ Ethnic } & \multirow{5}{*}{$\mathrm{P}=0.001$} \\
\hline Turk & $223(14.2)$ & $15(44.1)$ & \\
\hline Farse & $1322(84.3)$ & $19(55.9)$ & \\
\hline Kord & $21(1.3)$ & $0(0.0)$ & \\
\hline Baloch & $3(0.2)$ & $0(0.0)$ & \\
\hline \multicolumn{3}{|l|}{ BMI } & \multirow{3}{*}{$\mathrm{P}=0.33$} \\
\hline $\mathrm{BMI}<25$ & $1522(97.0)$ & $32(94.1)$ & \\
\hline $\mathrm{BMI}>25$ & $47(3.0)$ & $2(5.9)$ & \\
\hline \multicolumn{3}{|l|}{ Job } & \multirow{3}{*}{$P=0.41$} \\
\hline Employee & $87(5.5)$ & $3(8.8)$ & \\
\hline Other & $1482(94.5)$ & $31(91.2)$ & \\
\hline Gestational age & $1.9^{*} \pm 38.9$ & $39.4 \pm 1.2$ & $P=0.33$ \\
\hline Number of delivery & $0.88^{*} \pm 1.8$ & $2.35 \pm 1.12$ & $\mathrm{P}=0.01$ \\
\hline Number of pregnancy & $1.18^{*} \pm 2.16$ & $3.0 \pm 1.66$ & $\mathrm{P}=0.006$ \\
\hline City & $1074(98.5)$ & $16(1.5)$ & \multirow{2}{*}{$P=0.008$} \\
\hline Village & $495(96.5)$ & $18(3.5)$ & \\
\hline \multicolumn{3}{|l|}{ Asthma Familial history } & \multirow{3}{*}{$\mathrm{P}=0.001$} \\
\hline No & $1553(98.4)$ & $25(1.6)$ & \\
\hline Yes & $16(64.0)$ & $9(36.0)$ & \\
\hline
\end{tabular}

*T-test 
ders other than asthma and 1 patient had abortion in 9 weeks gestational age and 34 were clinically diagnosed with asthma. The prevalence of asthma was derived as $2.1 \%$. Demographic and obstetric characteristics of asthmatic and non-asthmatic pregnant women are shown in Table 1 . The highest frequency in the asthmatic patients group was in the age range of greater than or equal to 35 years ( $\geq 35$ category) - 20 (64.5\%) subjects. There was significant relationship between the number of pregnancy and delivery $p=0.01$ and $p=0.006$, respectively (Table 1 ). Frequency distribution of allergenic factors in pregnant women referred to Shahidan Mobini Hospital was another finding of this study. The most common allergen in non-asthmatic group was climate changes - 53 (3.4)_and in asthmatic group were pollen, stress and climate changes -5 (14.7) (Table 2).

Table 2. Frequency of allergenic factors in pregnant women referred to Shahidan Mobini Hospital in Sabzevar

\begin{tabular}{|c|c|c|}
\hline \multirow[t]{2}{*}{ Allergens } & $\begin{array}{c}\text { Non- } \\
\text { asthmatic }\end{array}$ & Asthmatic \\
\hline & N.\% & N.\% \\
\hline None & 1369 (87.3) & $2(5.9)$ \\
\hline Dust & $40(2.5)$ & $3(8.8)$ \\
\hline Cat & $3(0.2)$ & $0(0.0)$ \\
\hline Dog & $2(0.1)$ & $0(0.0)$ \\
\hline Pollen & $16(1.0)$ & $5(14.7)$ \\
\hline Reflux & $7(0.4)$ & $1(2.6)$ \\
\hline Stress & $0(0.0)$ & $5(14.7)$ \\
\hline Viral infection & $0(0.0)$ & $4(11.8)$ \\
\hline Exercise & $3(0.2)$ & $4(11.8)$ \\
\hline Climate & $53(3.4)$ & $5(14.7)$ \\
\hline Sinusitis & $16(1.0)$ & $1(2.9)$ \\
\hline Smoke & $7(0.4)$ & $3(8.8)$ \\
\hline Perfume & $9(0.6)$ & $0(0.0)$ \\
\hline Metoclopramide & $5(0.3)$ & $0(0.0)$ \\
\hline Pethidine & $22(1.4)$ & $1(2.9)$ \\
\hline potato & $2(0.1)$ & $0(0.0)$ \\
\hline Cigarette & $4(0.3)$ & $0(0.0)$ \\
\hline Hookah & $1(0.1)$ & $0(0.0)$ \\
\hline Ibuprofen & $1(0.1)$ & $0(0.0)$ \\
\hline Rhinestones & $2(0.1)$ & $0(0.0)$ \\
\hline $\begin{array}{l}\text { Garlic and } \\
\text { onion spice }\end{array}$ & $1(0.1)$ & $0(0.0)$ \\
\hline Surgical glue & $2(0.1)$ & $0(0.0)$ \\
\hline Dexamethasone & $3(0.2)$ & $0(0.0)$ \\
\hline Total & $1569(100.0)$ & $34(100.0)$ \\
\hline
\end{tabular}

Most of the subjects in the asthmatic group did not have eczema - $30(88.2 \%)$. The Chi-square test showed that the two groups are homogeneous Pvalue $=0.39$. The two groups were statistically significant for hospitalization due to respiratory problems as cold and respiratory tract infections $\mathrm{p}=$ 0.001 . The condition of most subjects with asthma was unchanged in the first and second trimester, $51.4 \%$ and $51.4 \%$, and worsened in the second and third trimester, $18.6 \%$ and $23.7 \%$, respectively. Regarding allergies, the highest level of allergy was in the asthmatic group $(32.1 \%) \mathrm{p}=(0.001)$.

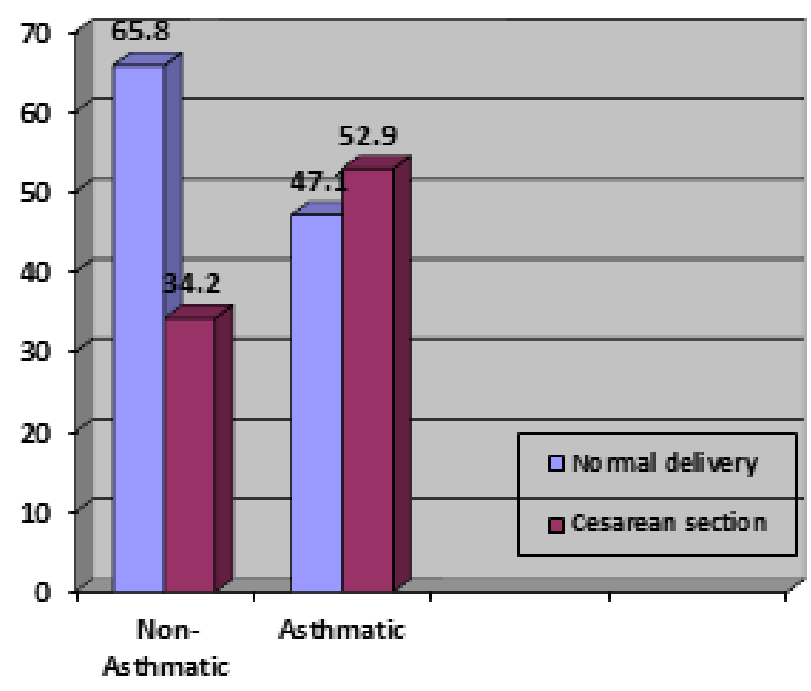

Figure 1. Frequency distribution of asthmatic and nonasthmatic pregnant women referred to Shahidan Mobini Hospital in Sabzevar City by type of delivery

In terms of delivery method, most of the research units in the non-asthmatic group had normal delivery $-65.8 \%$ ( 1,033 subjects), and in the asthmatic the group cesarean section was more common - 18 $(52.9 \%)$. Chi-square test showed a statistically significant difference in terms of the delivery method in two groups $(p=0.02)$ (Figure 1$)$. The relationship between asthma in asthmatic women with other allergic diseases including eczema, allergy, rhinitis, and wheeze in Figure 2 showed a significant relationship between wheeze and coughing and allergy (Figure 2). We considered frequency of symptoms in pregnant women referred to Mobini hospital like having wheezing in spatial place like basement, high altitude and closed places (Table 3). Severity of asthma according to allergen factors in asthmatic patient was not significant (Table 4). Also, statistical relationship was not found between control of asthma and the presence of allergy (Table 5). 


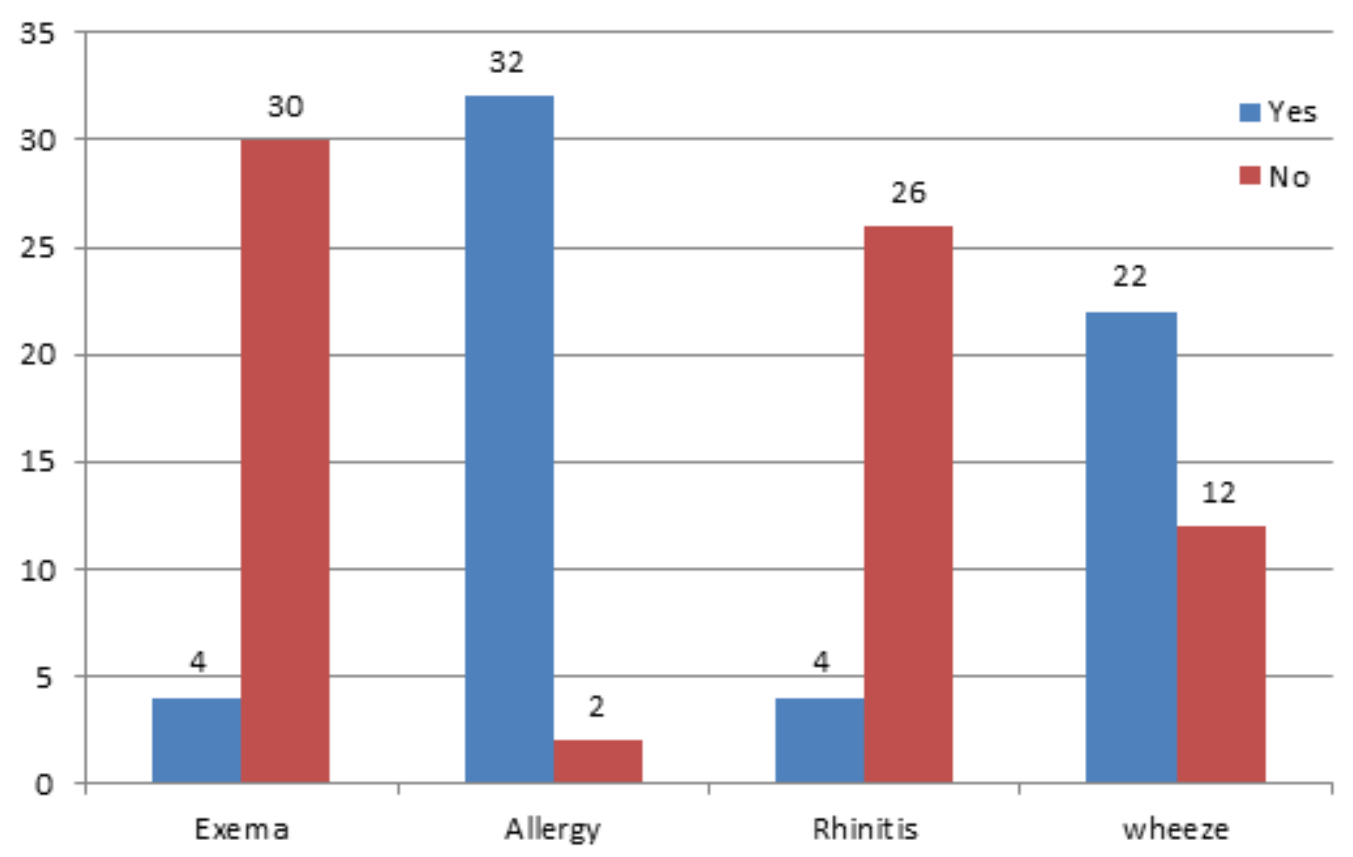

Figure 2. Relationship between asthma in asthmatic women with other allergic diseases including eczema, allergy, rhinitis, and wheeze

Table 3. Frequency of symptoms in pregnant women referred to Mobini hospital

\begin{tabular}{|c|c|c|c|c|}
\hline \multirow[t]{2}{*}{ Characteristic } & \multirow[t]{2}{*}{$\mathrm{Y} / \mathrm{N}$} & $\begin{array}{l}\text { Non- } \\
\text { asthmatic }\end{array}$ & Asthmatic & P value \\
\hline & & N.\% & N.\% & \\
\hline \multirow[t]{2}{*}{ Cough } & yes & $7(0.4)$ & $28(82.4)$ & \multirow[t]{2}{*}{$\mathrm{P}=0.001$} \\
\hline & no & $1562(99.6)$ & $6(17.6)$ & \\
\hline \multirow{2}{*}{$\begin{array}{l}\text { Seasonal } \\
\text { wheezing }\end{array}$} & yes & $8(0.5)$ & $22(64.7)$ & \multirow[t]{2}{*}{$\mathrm{P}=0.001$} \\
\hline & no & $1561(99.5)$ & $12(35.3)$ & \\
\hline \multirow{2}{*}{$\begin{array}{l}\text { Perfum } \\
\text { wheezing }\end{array}$} & yes & $6(0.4)$ & $28(82.4)$ & \multirow[t]{2}{*}{$\mathrm{P}=0.001$} \\
\hline & no & 1563 (99.6) & $6(17.6)$ & \\
\hline \multirow{2}{*}{$\begin{array}{l}\text { Wheezing in } \\
\text { spatial place }\end{array}$} & yes & $14(0.9)$ & $29(85.3)$ & \multirow[t]{2}{*}{$\mathrm{P}=0.001$} \\
\hline & no & 1555 (99.1) & $5(14.7)$ & \\
\hline \multirow{2}{*}{$\begin{array}{l}\text { Wheezing } \\
\text { after exercise }\end{array}$} & yes & $6(0.4)$ & $26(76.5)$ & \multirow[t]{2}{*}{$\mathrm{P}=0.001$} \\
\hline & no & 1563 (99.6) & $8(23.5)$ & \\
\hline \multirow{2}{*}{$\begin{array}{l}\text { Cough in } \\
\text { cold weather }\end{array}$} & yes & $3(0.2)$ & $17(50.0)$ & \multirow[t]{2}{*}{$\mathrm{P}=0.001$} \\
\hline & no & $1566(99.8)$ & $17(50.0)$ & \\
\hline \multirow[t]{2}{*}{ Allergy } & yes & 1369 (87.3) & $2(5.9)$ & \multirow[t]{2}{*}{$\mathrm{P}=0.001$} \\
\hline & no & $200(12.7)$ & $32(94.1)$ & \\
\hline
\end{tabular}


Table 4. Severity of asthma with reference to allergen factors in asthmatic patient

\begin{tabular}{|c|c|c|c|c|c|c|c|c|c|}
\hline \multirow[t]{2}{*}{ Severity of asthma } & \multicolumn{9}{|c|}{ Allergens } \\
\hline & None & Dust & Stress & Dog & Pollen & Reflux & Exercise & $\begin{array}{l}\text { Viral } \\
\text { infection }\end{array}$ & Climate \\
\hline & N.\% & N.\% & N.\% & N.\% & N.\% & N.\% & N.\% & N.\% & N.\% \\
\hline Intermittent & $2(100.0)$ & $1(50.0)$ & $3(50.0)$ & $0(0.0)$ & $1(50.0)$ & $1(100.0)$ & $0(0.0)$ & $1(33.3)$ & $4(28.6)$ \\
\hline Mild & $0(0.0)$ & $0(0.0)$ & $2(33.3)$ & $0(0.0)$ & $1(50.0)$ & $0(0.0)$ & $2(66.7)$ & $0(0.0)$ & $5(35.7)$ \\
\hline $\begin{array}{l}\text { Persistent } \\
\text { Moderate }\end{array}$ & $0(0.0)$ & $0(0.0)$ & $1(16.7)$ & $0(0.0)$ & $0(0.0)$ & $0(0.0)$ & $1(33.3)$ & $2(66.7)$ & $3(21.4)$ \\
\hline Severe & $(080.0)$ & $1(50.0)$ & $0(0.0)$ & $0(0.0)$ & $0(0.0)$ & $0(0.0)$ & $0(0.0)$ & $0(0.0)$ & $2(14.3)$ \\
\hline Fischer's exact test & \multicolumn{9}{|c|}{$\mathrm{P}=0.74$} \\
\hline
\end{tabular}

Table 5. Control of asthma with reference to having allergy

\begin{tabular}{l|c|c|c|c}
\hline \hline \multicolumn{2}{c|}{ Asthma control } & $\begin{array}{c}\text { Well } \\
\text { controlled }\end{array}$ & $\begin{array}{c}\text { Not well } \\
\text { controlled }\end{array}$ & $\begin{array}{c}\text { Poorly } \\
\text { controlled }\end{array}$ \\
\hline \multicolumn{2}{c}{ Allergy } & N.\% & N.\% & N.\% \\
\cline { 2 - 5 } & Yes & $11(84.6)$ & $18(100.0)$ & $3(100.0)$ \\
\hline Total & & $13(100.0)$ & $18(100.0)$ & $3(100.0)$ \\
\hline $\begin{array}{l}\text { Fischer's } \\
\text { exact test }\end{array}$ & \multicolumn{4}{|c}{$\mathrm{P}=0.31$} \\
\hline \hline
\end{tabular}

\section{DISCUSSION}

The results showed that the prevalence of asthma in pregnant women living in the Sabzevar region was $2.1 \%$. That is similar to the prevalence in India, according to Meena's study (14). In a 2007 study, Karimi et al. identified circa $5.6 \%$ of pregnant women as being asthmatic (12). However, the study of Mehrabi in Kurdistan indicated the prevalence of asthma in the adult population of 15 - 64 years old (3.2\%) (15). Wenders reported an Australian prevalence of asthma $12 \%$ (16). Demisse et al. observed that asthma affected $1.3 \%$ of pregnant women (17). Recent reports in the USA suggest that $3.7-8.4 \%$ of pregnant females had asthma during the span 1997 2001, which is an increase from $3.2 \%$ in the period 1988 - $1994(14,18)$. A probable reason for difference in asthma prevalence is in asthma diagnosis and asthma control that seem to differ by population characteristics (eg, age, race/ethnicity, socio-economic status), and further research and clinical involvement are needed to address a potentially systematic variation in reporting and management of the disease (19). Asthma worsened in about $23.7 \%$ of our subjects in the third trimester, while in one study, among women who completed the asthma control test during the clinical interview, $50 \%$ of women experienced worsening of asthma during pregnancy, differences of asthma severity in the various trimesters of pregnancy, which is probably due to the small sample size (13). It is also recognized that women with mild disease are still at risk of severe exacerbations during pregnancy, and for this reason, regular monitoring of asthma during pregnancy is recommended (20). Asthmatic women were classified according to the control level according to the GINA guidelines, which meant that $38.2 \%$ of subjects were well-controlled; $52.9 \%$ were not well controlled and $8.8 \%$ were poorly controlled. It is similar to the Meena's study in India, in which there were $51.9 \%, 42.3 \%$, and $5.8 \%$ of controlled, uncontrolled, and partly controlled subjects, respectively (14). In this regard, Brecken study is comparable to the present study (21). In the Karimi's study in Yazd, 5.6\% of women were referred to as asthmatics (12). This dispersal of prevalence in different parts of the country can be due to climate diversity and life patterns like diet, sleep patterns, smoking, 
physical activity, and body mass index. In addition, scorching temperatures and the desert climate in Sabzevar have led to social changes, with electric airconditioning being preferred to traditional methods of coping with the severe heat in Sabzevar. The oldest buildings, on the other hand, have the greatest thermal comfort. Few multicenter studies were carried out in China on associations between home environment factors (pet keeping, cats, dogs, cockroaches, rats, renovation activities, cooking fuels, lifestyle factors, living in a warmer climate zone etc.) and asthma or rhinitis among adults (22). In the Firoozi et al.'s study, mothers with severe asthma were in the upper level of BMI, while in the present study, subjects with asthma were more likely to be in the middle class of BMI. Most of the subjects with asthma were still living in the village, but in the Firozi's study, they were mostly living in the city. Most probably, the reason is the difference between urbanization and environmental pollution in the area where the study is performed. In addition, in the Firozi's study, preterm rate in the severe asthma group was more reported. However, there was no statistically significant difference in the present study. Perhaps, a small cohort of asthmatic patients was the reason (23). Unfortunately, the study's lack of standard process at the national level and in the asthma treatment system makes measuring the disease's burden extremely difficult. In this study, the lack of statistically significant differences in outcome, based upon the severity of asthma in the various trimesters of pregnancy, is probably due to the small sample size (1). The lack of maternal asthma responsiveness to progesterone or estriol suggests that other, i.e. non-hormonal factors may contribute to asthma's improvement during pregnancy and that the control of asthmatic airway smooth muscle may not be exactly the same as that of the myometrium and gut $(5,21)$. However, unlike Luik's study, we took into account physiological measurements such as spirometry, as well as symptoms, exacerbations of asthma, such as smoking, colds, and that it is the strength of the current study, while others only survived asthma symptoms (25, 26). The result was a significant association between asthma and age, place of residence, family history, and ethnicity, number of pregnancy and parity. However, neither BMI nor maternal literacy and job showed any significant correlation with maternal asthma status (i.e. asthmatic versus non-asthmatic). Luik's results regarding profession and race were similar to ours. The most commonly observed antigenic factors in this study included dust, cats, dogs, polen, gastroesophageal reflux, stress, viral infection, exercise, water, sinusitis, smoke, metoclopramide, penicillin, pethidine, potato, cigar, hookah, broffen, rabbit, onions, garlic, spice, glue, and non-metamorphic glue, which is similar in many cases to Ghaffari et al.'s study (27). In some cases, such as sycamore, pine, and asparagus, this is probably due to the geographical location difference (25).

For a more accurate assessment of the burden of asthma in the future, population-based research with a standard procedure for the epidemiological study of asthma, especially in pregnancy, should be designed to assess risk factors, the age at which the disease first appeared, the rate of asthma recovery, and the disease's economic and social consequences. Regarding the lack of sufficient information available in the health system of the country, it is appropriate for health policymakers to strengthen the existing care system in order to become more aware of the process of the disease in pregnancy in the country.

\section{CONCLUSION}

The current study found that even low levels of globally reported asthma are linked to an elevated risk for pregnant women during pregnancy, and that more research is needed to understand the incidence of asthma in pregnancy and its repercussions.

\section{Conflict of interest}

The authors declare having no conflict of interest.

\section{Acknowledgments}

This work was approved by the ethics committee of the Medical University of Sabzevar, Iran (Medsab Rec.93.36). We thank the personnel of Mobini and Vaseei Hospitals for their cooperation. We also thank all the mothers who participated in the study. Thanks and appreciation for the efforts of the headship of the university, Dr. Moslem, and the vice minister of research, Mr. Dr. Mohammadzadeh, for providing funding for the research project and the participants. We also thank Dr. Jacqueline C. Hodge who served as English language expert and scientific consultant. 


\section{References}

1. Belanger $K$, Hellenbrand ME, Holford TR, BrackenM. Effect of pregnancy on maternal asthma symptoms and medication use. Obstet Gynecol 2010; 115 (3):559.

https://doi.org/10.1097/AOG.0b013e3181d06945

2. Katz O, Sheiner E. Asthma and pregnancy: a review of two decades. Expert Rev Res Med 2008; 2(1):97107.

https://doi.org/10.1586/17476348.2.1.97

3. Virchow JC. Asthma and pregnancy. Semin Respir Crit Care Med 2012; 33:630-44. https://doi.org/10.1055/s-0032-1326961

4. Gluck JC, Gluck P. The effects of pregnancy on asthma: a prospective study. Ann Allergy 1976;37(3):164-8.

https:/pubmed.ncbi.nlm.nih.gov/962194/

5. Stenius-Aarniala B, Piirilä P, Teramo K. Asthma and pregnancy: a prospective study of 198 pregnancies. Thorax 1988; 43(1):12-18.

https://doi.org/10.1136/thx.43.1.12

6. Platts-Mills $\mathrm{T}$, Vaughan J, Squillace $\mathrm{S}$, et al. Sensitisation, asthma, and a modified Th2 response in children exposed to cat allergen: a populationbased cross-sectional study. The Lancet 2001; 357(9258):752-6.

https://doi.org/10.1016/S0140-6736(00)04168-4

7. Ritz T, Kullowatz A, Bobb C, et al. Psychological triggers and hyperventilation symptoms in asthma. Ann Allergy, Asthma Immunol 2008; 100(5):426-32.

https://doi.org/10.1016/S1081-1206(10)60466-8

8. Carroll KN, Griffin MR, Gebretsadik T, et al. Racial differences in asthma morbidity during pregnancy. Obstet Gynecol 2005; 106 (1): 66 -72. https://doi.org/10.1097/01.AOG.0000164471.87157.4c
9. Mendola P, Laughon SK, Männistö TI, et al. Obstetric complications among US women with asthma. Am J Obstet Gynecol 2013; 208(2):127. e1- e8. https://doi.org/10.1016/j.ajog.2012.11.007

10. Mendes RFP, Nomura RMY, Ortigosa C, Asthma during pregnancy: effects on fetal well-being, and maternal and perinatal complications. Revista da Associação Médica Brasileira. 2013; 59(2):113-19. https://doi.org/10.1016/S2255-4823(13)70443-0

11. Reddel HK, Levy ML. The GINA asthma strategy report: what's new for primary care? NPJ Primary care Res Med 2015; 25(1):1-4.

https://doi:10.1038/npjpcrm.2015.50

12. Karimi M, Davar R, Mirzaei M, Mirzaei $M$. Pregnancy outcomes in asthmatic women. Iranian J Allergy, Asthma Immunol 2008:105-6. file://C:/Users/fazel/Downloads/208Article\%20Text-208-1-10-20151001.pdf

13. Reddel HK, Bateman ED, Becker A, et al. A summary of the new GINA strategy: a roadmap to asthma control. Eur Res J 2015; 46(3):622-39. https://doi.org/10.1183/20734735.007915

14. Meena BL, Singh V, Sameja P, et al. A study of neonatal and maternal outcomes of asthma during pregnancy. Int J Res Med Sci 2013; 1:23-27. https://doi.org/10.5455/2320-6012.ijrms20130206

15. Mehrabi s. DelavariA, Moradigh, Ghaderi A. The prevalence of bronchial asthma in the population 15-64 years of Kurdistan in Iran. J Pharm Res Int 22(3):1-7.

https://doi.org/10.9734/JPRI/2018/38645

16. Vanders RL, Murphy VE. Maternal complications and the management of asthma in pregnancy. 
Womens Health (LondEngl) 2015; 11(2):183-91. https://doi.org/10.2217/WHE.14.69

17. Demissie K, Breckenridge MB, Rhoads GG. Infant and maternal outcomes in the pregnancies of asthmatic women. Am J Res Critical Care Med 1998; 158(4):1091-5.

https://doi.org/10.1164/ajrccm.158.4.9802053

18. Murphy VE. Maternal complications and the management of asthma in pregnancy. Womens Health (LondEngl) 2015; 11(2):183-91.

https://doi.org/10.2217/whe.14.69

19. Kwon HL, Triche EW, Belanger K, Bracken MB. The epidemiology of asthma during pregnancy: prevalence, diagnosis, and symptoms. Immunol Allergy Clinics 2006; 26 (1): 29-62.

https://doi.org/10.1016/j.iac.2005.11.002

20. Murphy VE. Managing asthma in pregnancy. Breathe 2015; 11(4):258-67. https://doi.org/10.1183/20734735.007915

21. Bracken MB, Triche EW, Belanger K, et al. Asthma symptoms, severity, and drug therapy: a prospective study of effects on 2205 pregnancies. Obstet Gynecol 2003; 102(4):739-52. https://doi.org/10.1016/s0029-7844(03)00621-5
22. Wang J, Zhang Y, Li B, et al. Asthma and allergic rhinitis among young parents in China in relation to outdoor air pollution, climate and home environment. Sci Total Environ 2021; 751:141734. https://doi.org/10.1016/j.scitotenv.2020.141734

23. Firoozi F, Lemière $C$, Ducharme FM, et al. Effect of maternal moderate to severe asthma on perinatal outcomes. Res Med 2010; 104(9):1278-87. https://doi.org/10.1016/j.rmed.2010.03.010

24. Heidarnia MA, Entezari A, Moein M, et al. Prevalence of asthma symptom in Iran: a metaanalysis. Res Med 2007; 31 (3):217-25.

https://www.researchgate.net/publication/301525825

25. Louik C, Schatz M, Hernández-Díaz S, et al. Asthma in pregnancy and its pharmacologic treatment. Ann Allergy, Asthma Immunol 2010; 105 (2): 110-17.

https://doi.org/10.1016/j.anai.2010.05.016

26. Fazel N, Kundi M, Jensen-Jarolim E, et al. Prospective cohort study of pregnancy complications and birth outcomes in women with asthma. Arch Gynecol Obstet 2018; 298(2):279-87 https://doi.org/10.1007/s00404-018-4800-y

27. Ghaffari J, Rafatpanah H, Nazari Z, Ghaffari R. Skin prick test in asthmatic, allergic rhinitis and urticaria patients. Med J Mashhad University Medical Sci 2011; 54(1):44-49. https://doi.org/10.4103/0019-5154.152513 


\title{
Prevalencija astme i drugih alergijskih oboljenja kod trudnica
}

\author{
Nasrin Fazel1,2, Asghar Kazemzadeh ${ }^{3}$, Mojtaba Fattahi Abdizadeh³, Erika Jensem-Jarolim4, \\ Shohreh Shahrouyan ${ }^{5}$, Sina Shahrooyan ${ }^{6}$ \\ ${ }^{1}$ Iranski istraživački centar za zdravo starenje, Departman za medicinsko-hirurško sestrinstvo, \\ Fakultet za sestrinstvo i akušerstvo, Univerzitet medicinskih nauka u Sabzevaru, Sabzevar, Iran \\ ${ }^{2}$ Student doktorskih studija u Centru za javno zdravlje, Medicinski univerzitet u Beču, Beč, Austrija \\ ${ }^{3}$ Univerzitet medicinskih nauka u Sabzevaru, Sabzevar, Iran \\ ${ }^{4}$ Institut za patofiziologiju i ispitivanje alergija, Medicinski univerzitet u Beču, Beč, Austrija \\ ${ }^{5}$ Hakim Univerzitet u Sabzevaru, Sabzevar, Iran \\ ${ }^{6}$ Moskovski državni univerzitet za medicinu i stomatologiju "A.I. Evdokimov", Moskva, Rusija
}

\section{SAŽETAK}

Astma i ostale alergijske bolesti mogu da utiču na ishod trudnoće. Astma i alergije česti su komorbiditeti tokom trudnoće i egzacerbacije su glavni klinički problem. Rezultati studija se razlikuju. Stoga je cilj ove studije bilo određivanje učestalosti astme i alergijskih bolesti tokom trudnoće.

Ova prospektivna kohortna studija urađena je na prenatalnoj klinici Mobini bolnice u Iranu. Učestvovale su ukupno 1603 trudnice pre 24. nedelje trudnoće. Sve učesnice intervjuisane su o alergijskim bolestima, okidačima za nastanak alergijske bolesti i stepenu težine astme. Takođe, kontrola astme urađena je prema GINA smernicama. Dijagnoza astme bazirana je na simptomima, dijagnozi pulmologa i rezultatu spirometrije. Rezultati su analizirani pomoću SPSS verzije 20, t-testova, kao i Chi-square testa.

Prevalencija astme kod učesnica u toku trudnoće iznosila je 2,1\%. Najčešći alergeni u grupi astmatičara bili su polen, stres i klimatski uslovi. Uočen je značajan odnos između godina starosti, obrazovanja i mesta stanovanja između astmatičara $i$ ispitanica bez astme; $p=0,003, p=0,05, p=0,008$. Takođe, zabeležen je značajan odnos simptoma astme među grupama $(p=0,001)$. Pored toga, utvrđen je značajan odnos astme $i$ ostalih alergijskih bolesti ukljičujući ekcem, alergiju, rinitis i vizing kod žena sa astmom, sa takođe značajnim odnosom vizinga, kašlja i alergije.

Izlaganje trudnica visokim nivoima alergena, poput polena $\mathrm{i}$ alergijskih bolesti, dovelo je do povećanja rizičnog ishoda trudnoće. Promišljeno lečenje ovih bolesti bi trebalo da spreči većinu ozbiljnih komplikacija.

Ključne reči: alergen, trudnoća, astma 